\title{
Isolasi dan Identifikasi Bakteri Asam Laktat Proteolitik dari Susu Kedelai yang Terfermentasi Spontan
}

\author{
Yusmarini ${ }^{12^{*}}$, Retno Indrati ${ }^{2)}$, Tyas Utami ${ }^{2}$, dan Yustinus Marsono ${ }^{2)}$ \\ 1)Program Studi Teknologi Hasil Pertanian, Universitas Riau, Pekanbaru \\ ${ }^{2}$ Fakultas Teknologi Pertanian, Universitas Gadjah Mada, Yogyakarta \\ Diterima 05-02-2009 Disetujui 10-06-2009
}

\begin{abstract}
Lactic acid bacteria is a group of bacteria with proteolytic activities enambling to grow on protein rich substrate such as soymilk. This research was aim to isolate and identify lactic acid bacteria with have proteolytic activity from spontaneous fermented soy milk. Sixteen isolates out of 26 colonies isolated from fermented soymilk are presumed as lactic acid bacteria. Among these 16 isolates, only 3 of them showed proteolytic activity. These three isolates were further identify morphologically and only two isolates identified as Lactic Acid Bacteria, namely R.1.3.2 and R.11.1.2. The ability of these isolates to produce acid and protease were observed. The results showed that isolate $\mathbf{R}$ 1.2.3 higher ability in producing protease.
\end{abstract}

Keywords: fermented soymilk, isolation and identification, lactic acid bacteria, proteolytic activity

\section{PENDAHULUAN}

Produk fermentasi dari susu kedelai merupakan salah satu produk olahan susu kedelai yang dibuat dengan menambahkan bakteri asam laktat (BAL). Produk ini dikenal mempunyai efek menguntungkan bagi kesehatan diantaranya dapat menurunkan kolesterol (hipokolesterolemik). Efek hipokolesterolemik dari susu fermentasi dapat berasal dari BAL yang digunakan (Lestari et al., 2004) maupun dari senyawa bioaktif seperti peptida yang merupakan hasil hidrolisis protein oleh enzim protease yang dihasilkan oleh bakteri asam laktat (Nisa et al., 2006).

Tidak semua BAL dapat hidup dengan baik pada susu kedelai. Hal ini disebabkan karena tidak semua BAL menghasilkan enzim $\alpha$-galaktosidase yang dibutuhkan untuk menghidrolisis rafinosa dan stakiosa yang banyak terdapat pada susu kedelai. Hanya BAL yang mampu memanfaatkan karbohidrat yang ada pada susu kedelai terutama rafinosa dan stakiosa yang dapat hidup dan berkembang biak dengan baik. Streptococcus thermophilus dan Lactobacilus bulgaricus tidak dapat tumbuh dan berkembang biak dengan baik pada susu kedelai kecuali jika susu kedelai tersebut ditambah gula seperti sukrosa, laktosa dan glukosa. Tanasupawat, (1993), menyatakan bahwa beberapa BAL yang diisolasi dari beberapa tanaman

\footnotetext{
*Telp: +628127699124

Email: marinithp@yahoo.co.id
}

dapat memanfaatkan rafinosa seperti Lactobacilus pentosus strain FP21-1 (bamboo shoot), FP41-1 (tea leaves), dan F18-1 (vegetable). (Bordignon et al., 2004) menambahkan bahwa Bifidobacterium bifidum JCM 1255, B. breve JCM 1192, B. infantis JCM 1222, serta L. casei subsp. rhamnosus IFO 3425 juga dapat memanfaatkan rafinosa dan stakiosa yang terdapat pada kedelai. Kenyataan ini menunjukkan bahwa rafinosa dan stakiosa yang terdapat pada kedelai sebenarnya dapat dimanfaatkan oleh bakteri-bakteri tertentu. Di dalam susu susu kedelai yang terfermentasi secara spontan akan tumbuh dan berkembang biak bermacam-macam mikrobia dan kemungkinan diantaranya adalah bakteri asam laktat yang dapat menghasilkan enzim $\alpha$-galaktosidase yang dibutuhkan untuk menghidrolisis rafinosa dan stakiosa yang terdapat pada susu kedelai.

Bakteri asam laktat mempunyai sistem proteolitik yang kompleks yang dibutuhkan untuk pertumbuhan BAL itu sendiri dan juga memberi kontribusi yang nyata pada pembentukan flavour produk fermentasi. Menurut (Piraino et al., 2007) aktivitas proteolitik S. thermophilus lebih rendah dibandingkan $L$. casei, $L$. helveticus, $L$. Rhamnosus, dan Lc. lactis, namun S. thermophilus memproduksi asam lebih cepat. Garabal et al., (2007), menyatakan bahwa Lactococcus lactis mempunyai aktivitas proteolitik lebih besar dibandingkan Lactobacilli dan Leuconostoc. Diharapkan dengan mengisolasi BAL 
dari susu kedelai yang terfermentasi secara spontan akan diperoleh isolat BAL yang mampu memfermentasi susu kedelai dan menghasilkan enzim protease yang akan menghidrolisis protein menjadi peptida yang mampu menurunkan kolesterol plasma. Tujuan dari penelitian ini adalah untuk mengisolasi dan mengidentifikasi BAL proteolitik dari susu kedelai yang terfermentasi spontan.

\section{BAHAN DAN METODE}

Bahan yang digunakan dalam penelitian ini adalah kacang kedelai varietas Anjasmoro yang diperoleh dari Balai Benih Tanaman Palawija - Wonosari dan bahanbahan kimia diantaranya MRS broth (Merck), $\mathrm{NaCl}$ (Merck), $\mathrm{CaCO}_{3}$ (Merck), agar teknis, dan susu skim (Lactona) serta bahan-bahan lainnya yang diperlukan untuk isolasi dan identifikasi bakteri asam laktat serta uji aktivitas proteolitik.

Pembuatan Susu Kedelai. Susu kedelai dibuat dengan menggunakan metode Pusbangtepa IPB (Nisa et al., 2006) dengan sedikit modifikasi. Biji kedelai kering disortir dan direndam dalam air selama 8 jam, kemudian dicuci dan ditiriskan lalu direbus hingga matang dan dicuci. Kedelai matang dihancurkan dengan blender sambil ditambahkan air panas dengan perbandingan $1: 6$, lalu disaring dengan menggunakan kain bersih yang telah dicuci dengan air panas. Susu kedelai yang dihasilkan kemudian dimasak pada suhu $\pm 80^{\circ} \mathrm{C}$ selama 5 menit dan dimasukkan ke dalam 4 botol kaca. Dua botol susu kedelai ditambah gula pasir sebanyak $0.5 \%$ sedangkan dua botol tidak ditambah gula. Kemudian botol ditutup dengan alumuniun foil dan plastik lalu diinkubasi pada suhu $37^{\circ} \mathrm{C}$ selama $1-2$ hari sehingga terfermentasi secara spontan. Setelah itu diamati nilai $\mathrm{pH}$ dan aroma dari susu kedelai yang telah terfermentasi secara spontan dan selanjutnya dilakukan isolasi serta pemurnian terhadap isolat yang tumbuh.

Isolasi dan Pemurnian Isolat. Isolasi bakteri asam laktat menggunakan metode pour plate, dimana $1 \mathrm{~mL}$ susu kedelai yang telah difermentasi secara spontan dimasukkan ke dalam $9 \mathrm{~mL}$ larutan $0.85 \%$ garam fisiologis steril dan digojog. Kemudian dilakukan serial pengenceran sampai dengan $10^{-8}$. Dari masingmasing seri pengenceran diambil $1 \mathrm{~mL}$ dan diinokulasi pada media MRS agar yang telah ditambah $0.2 \%$ $\mathrm{CaCO}_{3}$. Inkubasi dilakukan pada suhu $37^{\circ} \mathrm{C}$ selama 1 -
2 hari. Isolat yang membentuk zona jernih pada media MRS agar dan memiliki kenampakan berbeda diisolasi dan dilakukan pemurnian dengan metode goresan (spread plate) pada media yang sama. Perlakuan ini diulang 3 kali sehingga akan diperoleh isolat murni.

Uji aktivitas proteolitik (kualitatif). Isolat yang diduga BAL diuji aktivitas proteolitiknya secara kualitatif dengan menggunakan metode (Dakwa et al., 2005) dengan sedikit modifikasi. Aliquot dari suspensi jernih ditusukkan pada media skim milk agar yang mengandung 3\% skim milk dan 3\% agar. Inkubasi dilakukan pada suhu $37^{\circ} \mathrm{C}$ selama 1-3 hari. Isolat yang mempunyai aktivitas proteolitik akan membentuk zona jernih pada media skim milk agar. Diameter zona jernih diukur untuk masing-masing isolat.

Identifikasi Bakteri Asam Laktat. Identifikasi isolat BAL dilakukan berdasarkan pada karakteristik morfologi (bentuk sel), uji katalase, pewarnaan Gram, motilitas, dan tipe fermentasi (Rahayu \& Margino, 1997). Isolat murni yang menunjukkan kriteria katalase negatif (-), Gram positif (+), dan non motil diidentifikasi sebagai BAL.

\section{HASIL DAN PEMBAHASAN}

Nilai pH dan aroma susu kedelai yang terfermentasi spontan. Hasil penelitian menunjukkan bahwa proses fermentasi secara spontan pada susu kedelai akan mengakibatkan terjadinya penurunan nilai $\mathrm{pH}$. Susu kedelai sebelum difermentasi mempunyai $\mathrm{pH}$ 6.7 dan setelah difermentasi secara spontan selama 1-2 hari terjadi penurunan nilai $\mathrm{pH}$ yakni berkisar antara 4.94-538 seperti terlihat pada Tabel 1.

Data pada Tabel 1 menunjukkan bahwa susu kedelai yang ditambah gula sebanyak $0,5 \%$ dan difermentasi selama 1 hari mempunyai pH lebih rendah dibandingkan dengan perlakuan tanpa penambahan gula. Meskipun demikian pada perlakuan tanpa penambahan gula juga terjadi penurunan nilai $\mathrm{pH}$ namun penurunan tersebut tidak setinggi perlakuan yang ditambah gula. Hal ini menunjukkan bahwa mikrobia yang terdapat pada susu kedelai tersebut mampu memanfaatkan sumber gula yang ada pada susu kedelai terutama sukrosa, rafinosa dan stakiosa dan menghasilkan asam. Hasil penelitian ini sejalan dengan pernyataan Tanasupawat, (1993), yang menyatakan bahwa beberapa BAL yang diisolasi dari beberapa 
Tabel 1. Nilai pH dan aroma susu kedelai yang terfermentasi secara spontan

\begin{tabular}{clcc}
\hline No. & \multicolumn{1}{c}{ Pengamatan } & Nilai pH & Aroma \\
\hline 1. & Fermentasi selama 1 hari pada suhu $37^{\circ} \mathrm{C}$ & 5,38 & Berbau asam $(+)$ \\
a. & Susu kedelai tanpa penambahan gula & 4,94 & Berbau lebih asam $(++)$ \\
b. & Susu kedelai ditambah gula $0,5 \%$ & & Berbau asam dan sedikit busuk (+) \\
& & & Berbau busuk (++) \\
2. & Fermentasi selama 2 hari pada suhu $37^{\circ} \mathrm{C}$ & 5,10 & \\
a. & Susu kedelai tanpa penambahan gula & & \\
b. & Susu kedelai ditambah gula 0,5\% & & \\
\hline
\end{tabular}

Tabel 2. Hasil isolasi dan pemurnian pada media MRS Agar

\begin{tabular}{|c|c|c|}
\hline $\mathrm{NO}$ & Kode Isolat & Zona Jernih (MRS) \\
\hline 1. & R.1.2.2 & + \\
\hline 2. & R.1.3.2 & + \\
\hline 3. & R.2.1.1 & + \\
\hline 4. & R.2.1.2 & + \\
\hline 5. & R.3.1.2 & + \\
\hline 6. & R.4.1.2 & + \\
\hline 7. & R.5.1.2 & + \\
\hline 8. & R.8.1.2 & + \\
\hline 9. & R.9.4.2 & + \\
\hline 10. & R.9.4.3 & + \\
\hline 11. & R.10.1.1 & + \\
\hline 12. & R.10.1.2 & + \\
\hline 13. & R.10.3.2 & + \\
\hline 14. & R.10.4.2 & + \\
\hline 15. & R.10.5.2 & + \\
\hline 16. & R.11.1.2 & + \\
\hline 17. & R.1.2.1 & - \\
\hline 18. & R.4.2.1 & - \\
\hline 19. & R.7.1.2 & - \\
\hline 20. & R.9.4.1 & - \\
\hline 21. & R.9.3.1 & - \\
\hline 22. & R.9.3.2 & - \\
\hline 23. & R.10.3.1 & - \\
\hline 24. & R.10.4.1 & - \\
\hline 25. & R.10.6.1 & - \\
\hline 26. & R.10.6.2 & - \\
\hline
\end{tabular}

tanaman dapat memanfaatkan rafinosa dan stakiosa seperti L. pentosus yang diisolasi dari tumbuhtumbuhan dapat memanfaatkan rafinosa yang terkandung pada kedelai. Bordignon et al., (2004) juga melaporkan bahwa Bifidobacterium bifidum JCM 1255, B. breve JCM 1192,dan B.infantis JCM 1222 serta L.casei subsp.rhamnosus IFO 3425 dapat memanfaatkan rafinosa dan stakiosa yang terdapat pada kedelai.

Penambahan sumber gula berupa sukrosa mampu memacu pertumbuhan mikrobia. Mikrobia terutama bakteri asam laktat akan memetabolisir karbohidrat menjadi energi yang dibutuhkan untuk pertumbuhan sel bakteri dan dari hasil metabolisir tersebut juga akan dihasilkan asam-asam organik yang menyebabkan terjadinya penurunan $\mathrm{pH}$ susu kedelai. Namun setelah difermentasi selama dua hari, susu kedelai yang ditambah gula menunjukkan peningkatan nilai $\mathrm{pH}$ yakni dari 4,94 pada hari pertama menjadi 5,07 pada hari kedua. Hal ini disebabkan karena adanya degradasi protein lebih lanjut menjadi amonia yang mengakibatkan terjadinya peningkatan nilai $\mathrm{pH}$ dan timbulnya aroma busuk pada susu kedelai fermentasi.

Inkubasi dilakukan pada suhu $37^{\circ} \mathrm{C}$ dimana bakteri asam laktat umumnya tumbuh pada kisaran suhu tersebut. Menurut Steamer (1979) bakteri asam laktat mempunyai suhu pertumbuhan yang optimun pada kisaran $30-40^{\circ} \mathrm{C}$. Namun hasil penelitian pendahuluan menunjukkan bahwa inkubasi yang dilakukan pada suhu kamar $\left(30^{\circ} \mathrm{C}\right)$ akan menghasilkan susu kedelai yang berbau busuk karena bakteri pembusuk lebih dominan tumbuh pada suhu tersebut. Oleh karena itu inkubasi susu kedelai dilakukan pada suhu $37^{\circ} \mathrm{C}$.

Isolasi dan Pemurnian Isolat. Setelah dilakukan isolasi mikrobia dari susu kedelai yang terfermentasi spontan dan dilakukan pemurnian diperoleh sebanyak 26 isolat. Dari 26 isolat yang diperoleh hanya 16 isolat yang menghasilkan zona jernih pada media MRS Agar yang ditambah $\mathrm{CaCO}_{3}$ (Tabel2) yang mengindikasikan adanya produksi asam dari isolat tersebut. Keenambelas isolat ini diduga sebagai bakteri asam laktat. Dua contoh isolat yang dominan menghasilkan asam disajikan pada Gambar 1.

Isolat yang diduga sebagai bakteri asam laktat kemudian diuji kemampuannya menghasilkan enzim protease pada media skim milk agar. Hasil pengujian terlihat pada Gambar 2 dan Tabel 3.

Dari 16 isolat yang diduga sebagai bakteri asam laktat, hanya 3 isolat yang mampu menghasilkan enzim protease yakni R1.3.2 ; R.10.5.2 dan R.11.1.2. Namun setelah dilakukan identifikasi secara mikroskopis, uji katalase dan biokimia hanya isolat R.1.3.2 dan R.11.1.2 yang teridentifikasi sebagai bakteri asam laktat.

Zona jernih yang dihasilkan oleh isolat R.1.3.2 dan R.11.1.2 pada media skim milk (Gambar 2) 

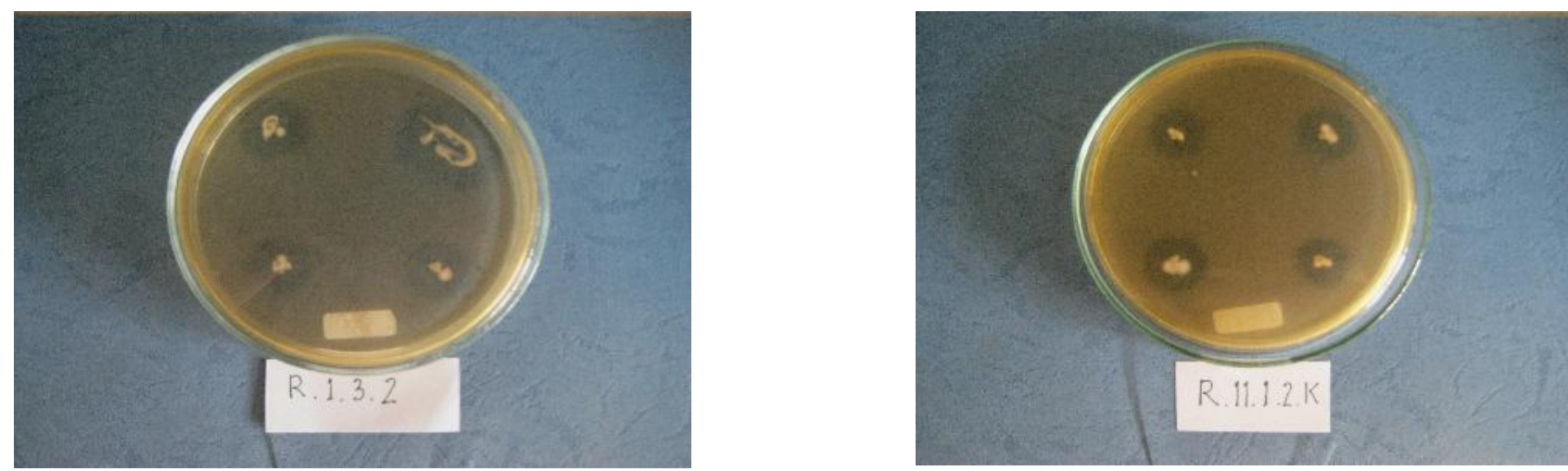

Gambar 1. Kemampuan isolat R.1.3.2 dan R.11.1.2.K untuk memproduksi asam pada media MRS agar

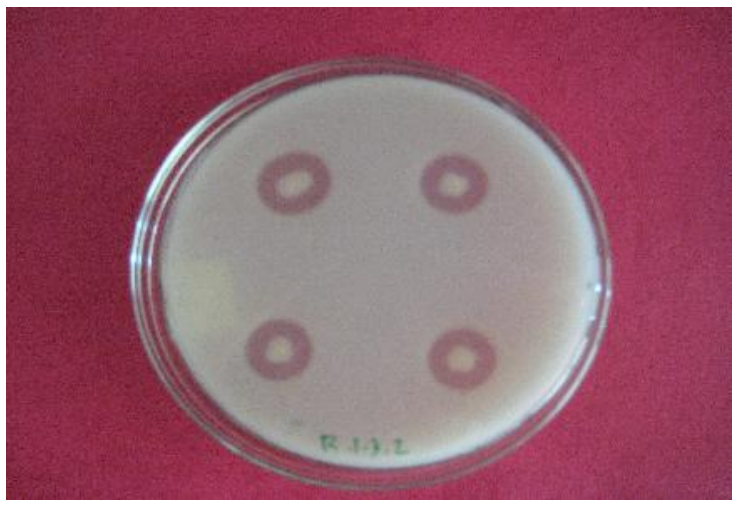

Isolat R.1.3.2

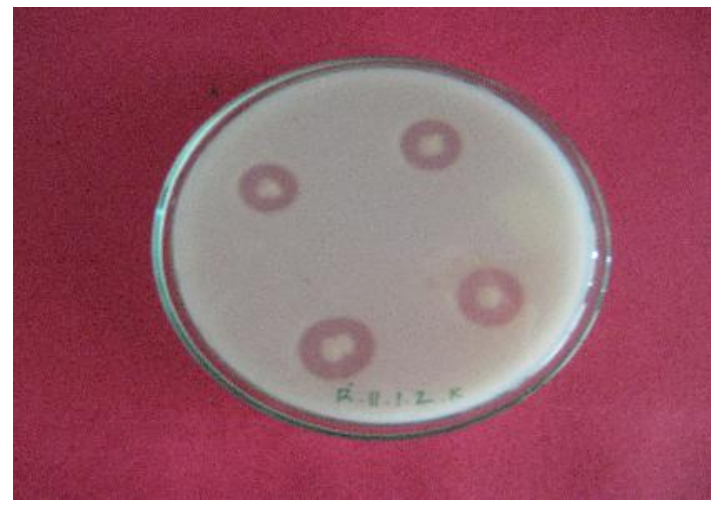

Isolat R.11.1.2

Gambar 2. Kemampuan proteolitik isolat R.1.3.2 dan R.11.1.2 pada media skim milk agar

menunjukkan kemampuan kedua isolat tersebut dalam memproduksi enzim protease. Semakin besar zona jernih yang dihasilkan berarti semakin besar pula kemampuan isolat tersebut untuk menghasilkan enzim protease.

Dari hasil pengukuran diameter zona jernih (Tabel 3) diketahui bahwa ada perbedaan kemampuan isolat dalam menghasilkan enzim protease. Isolat R.1.3.2 dan R.10.5.2 mempunyai diameter zona jernih sedikit lebih besar dibandingkan dengan isolat R.11.1.2 baik pada hari pertama maupun hari ketiga inkubasi. Hal ini mengindikasikan bahwa isolat R.1.3.2 dan R.10.5.2 secara kualitatif mempunyai kemampuan proteolitik lebih besar dibandingkan isolat R.1.1.2. Nakazawa \& Hosono, (1992), menyatakan bahwa aktivitas proteolitik dari BAL berbeda untuk masing-masing strain sekalipun berada dalam satu spesies. Hasil penelitian (Gobbetti et al., 1996) menunjukkan bahwa aktivitas spesifik dari enzim protease yang dihasilkan oleh L. plantarum DC400 lebih besar dibanding L.acidophilus BF4 maupun

\section{L.fermentum CC5.}

Identifikasi bakteri asam laktat. Isolat yang menghasilkan asam yang ditandai dengan adanya zona jernih pada media MRS agar dan mempunyai aktivitas proteolitik, kemudian diidentifikasi lebih lanjut. Hasil identifikasi yang meliputi pewarnaan Gram, uji katalase dan produksi gas disajikan pada Tabel 4 sedangkan bentuk morfologis dari isolat disajikan pada Gambar 3. Pengamatan adanya zona jernih baik pada media MRS agar maupun pada media skim milk agar dilakukan setelah masing-masing isolat diinokulasi pada media dan diinkubasi pada suhu $37^{\circ} \mathrm{C}$ selama 24 dan 48 jam.

Berdasarkan data pada Tabel 4 diketahui bahwa dari 3 isolat yang menghasilkan asam dan mempunyai aktivitas proteolitik ternyata hanya 2 isolat yang teridentifikasi sebagai bakteri asam laktat yakni isolat R.1.3.2 dan R.11.1.2. Wood, (1992), menyatakan bahwa kriteria bakteri asam laktat antara lain gram positif, katalase negatif, berbentuk batang atau bulat dan dapat bersifat homofermentatif ataupun heterofermentatif

Ada perbedaan kemampuan isolat untuk menghasilkan asam yang terlihat dari adanya zona jernih pada media MRS agar. Diameter zona jernih pada media MRS agar yang dihasilkan oleh isolat R.11.1.2 pada 24 jam pertama inkubasi sedikit lebih besar dibandingkan dengan isolat R.1.3.2. Diduga bahwa kemampuan isolat R.11.1.2 untuk menghasilkan asam pada media MRS sedikit lebih tinggi atau isolat tersebut lebih cepat menghasilkan asam dibanding R.1.3.2 pada 
24 jam pertama inkubasi. Namun pada 48 jam inkubasi kemampuan R.11.1.2 untuk menghasilkan asam lebih rendah dibandingkan dengan R.1.3.2. (Tabel 4) secara kualitatif. Menurut Angeles \& Marth (1971) produksi asam tergantung pada kemampuan mikroorganisme dalam menggunakan karbohidrat yang terdapat dalam medium. Selanjutnya Piraino et al., (2007), menyatakan bahwa kemampuan bakteri asam laktat untuk menghasilkan asam berbeda-beda dan dinyatakan bahwa Streptococcus thermophilus memproduksi asam lebih cepat dibandingkan Lactobacillus casei, L. helveticus, L. Rhamnosus, dan Lactococcus lactis.

Tabel 3. Hasil pengujian zona jernih pada media Skim Milk Agar

\begin{tabular}{|c|c|c|c|}
\hline \multirow{2}{*}{$\mathrm{NO}$} & \multirow{2}{*}{ Kode Isolat } & \multicolumn{2}{|c|}{ Diameter Zona Bersih (SKIM) } \\
\hline & & Hari Pertama & Hari Ketiga \\
\hline 1. & R.1.2.2 & - & - \\
\hline 2. & R.1.3.2 & $0,825 \mathrm{~cm}$ & $1,725 \mathrm{~cm}$ \\
\hline 3. & R.2.1.1 & - & - \\
\hline 4. & R.2.1.2 & - & - \\
\hline 5. & R.3.1.2 & - & - \\
\hline 6. & R.4.1.2 & - & - \\
\hline 7. & R.5.1.2 & - & - \\
\hline 8. & R.8.1.2 & - & - \\
\hline 9. & R.9.4.2 & - & - \\
\hline 10. & R.9.4.3 & - & - \\
\hline 11. & R.10.1.1 & - & - \\
\hline 12. & R.10.1.2 & - & - \\
\hline 13. & R.10.3.2 & - & - \\
\hline 14. & R.10.4.2 & - & - \\
\hline 15. & R.10.5.2 & $0,825 \mathrm{~cm}$ & $1,725 \mathrm{~cm}$ \\
\hline 16. & R.11.1.2 & $0,750 \mathrm{~cm}$ & $1,650 \mathrm{~cm}$ \\
\hline
\end{tabular}

Hasil pewarnaan Gram terhadap ketiga isolat yakni R.1.3.2, R.10.5.2, dan R.11.1.2 menunjukkan Gram positif (sel bakteri terlihat berwarna violet). Sedangkan dari hasil pengujian katalase diketahui bahwa isolat R.10.5.2 menunjukkan hasil yang positif. Berdasarkan kriteria ini dapat disimpulkan bahwa isolat R.10.5.2 tidak termasuk kelompok bakteri asam laktat.

Gambar 3 menunjukkan bahwa isolat R.1.3.2 dan R.11.1.2 mempunyai bentuk morfologis yang mirip yakni berupa batang pendek sedangkan $L$. acidophilus yang digunakan sebagai kontrol berbentuk batang panjang. Berdasarkan identifikasi kedua isolat tersebut yakni R.1.3.2 dan R.11.1.2 diduga termasuk genus Lactobacillus yang bersifat homofermentatif yang ditandai dengan tidak adanya gas pada tabung durham pada pengujian produksi gas (Tabel 4). Kelompok homofermentatif (homolaktat fermentatif) memproduksi 2 molekul asam laktat dari 1 molekul glukosa atau memproduksi asam laktat hampir $90 \%$, sedangkan kelompok heterofermentatif hanya memproduksi 1 glukosa (Fung, 1986 ; Schlegel 1994). ${ }_{2}$ dari 1 molekul

\section{KESIMPULAN DAN SARAN}

Berdasarkan hasil penelitian dapat disimpulkan bahwa proses fermentasi susu kedelai secara spontan melibatkan beberapa bakteri asam laktat. Berdasarkan hasil isolasi dan pemurnian dari susu kedelai yang terfermetasi secara spontan yang dilanjutkan dengan

Tabel 4. Identifikasi bakeri asam laktat

\begin{tabular}{|c|c|c|c|c|c|c|c|}
\hline \multirow{2}{*}{ No } & \multirow{2}{*}{ Kode Isolat } & \multicolumn{2}{|c|}{ Diameter Zona Jernih (MRS) } & \multirow{2}{*}{ Zona Jernih (SKIM) } & \multirow{2}{*}{ Gram } & \multirow{2}{*}{ Katalase } & \multirow{2}{*}{ Produksi Gas } \\
\hline & & 24 jam (cm) & 48 jam $(\mathrm{cm})$ & & & & \\
\hline 1. & R.1.3.2 & 1,000 & 2,100 & + & + & - & - \\
\hline 2. & R.10.5.2 & 0,700 & 1,300 & + & + & + & - \\
\hline 3. & R.11.1.2 & 1,075 & 1,975 & + & + & - & - \\
\hline
\end{tabular}

Keterangan : + membentuk zona jernih pada media, isolat berwarna violet, memiliki katalase - tidak memiliki katalase, tidak menghasilkan gas

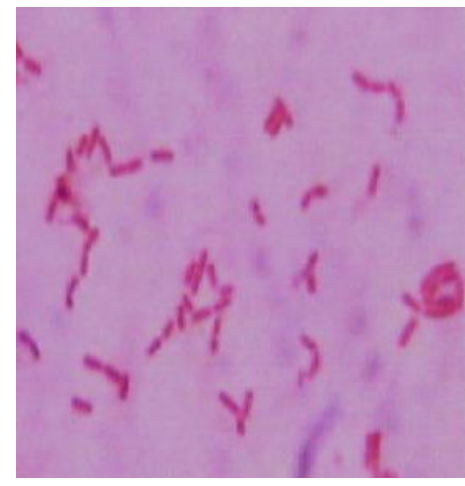

R.1.3.2

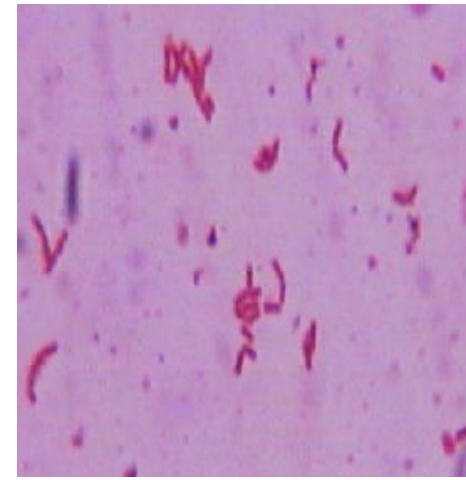

R.11.1.2

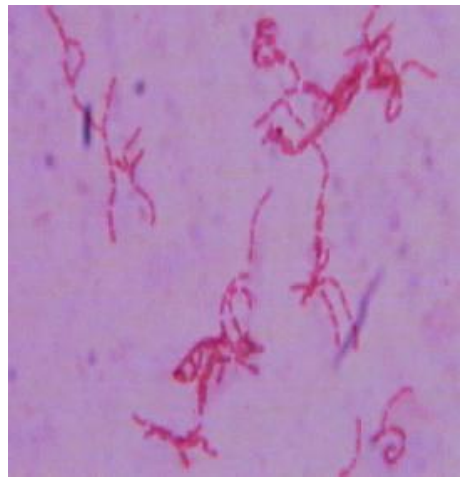

L. acidophilus

Gambar 3. Bentuk morfologis dari isolat R.1.3.2 ; R.11.1.2 dan L. acidophilus 
pengujian aktivitas proteolitik, diperoleh 2 isolat bakteri asam laktat proteolitik yakni R.1.3.2 dan R.11.1.2. Kedua isolat tersebut berbentuk batang pendek dan diduga termasuk genus Lactobacillus yang bersifat homofermentatif.

Pada 24 jam pertama inkubasi isolat R.11.1.2 menghasilkan asam lebih banyak dibandingkan R.1.3.2. Namun pada 48 jam inkubasi kemampuan R.11.1.2 untuk menghasilkan asam lebih rendah dibandingkan dengan R.1.3.2. Kemampuan isolat R.1.3.2 untuk memproduksi enzim proteinase yang didasarkan atas diameter zona jernih pada media skim milk agar sedikit lebih besar dibandingkan dengan R.11.1.2.

Perlu identifikasi molekuler dengan PCR untuk konfirmasi genus, spesies dan mengetahui strain dengan sequencer.

\section{UCAPAN TERIMA KASIH}

Penulis mengucapkan terima kasih kepada pengelola program I-MHERE Universitas Riau dan LPPM Universitas Gadjah mada yang telah mendanai penelitian ini.

\section{DAFTAR PUSTAKA}

Angeles, A.G. \& Marth, E.H. 1971. Growth and activity lactic acid bacteria in soy milk, growth and acids production. J. Milk Food Technol 34: 30.

Bordignon, J.R., Nakahara, K., Yoshihashi, T., \& Nikkuni, S. 2004. Hydrolysis of isoflavone and consumption of oligosacharides during lactic acid fermentation of soybean milk. JARQ 38: 259- 265.

Dakwa, S., Saiki, E., Dawson, Diako, C., Annan, N.T., \& AmoaAwua, W.K. 2005. Effect of boiling and roasting on the fermentation of soybeans into dawadawa (soy-dawadawa). International Journal of Food Microbiology 104: 69-82

Fung, D.Y.C. 1986. Types of microorganisms. ch.2. Di dalam: Cunningham, F.E. \& Cox, N.A. The Microbiology of Poultry Meat Product. New York: Academic Press Inc.

Garabal, J.I., Alonso, P.R., \& Centeno, J.A. 2007. Characterization of lactic acid bacteria isolated from raw cow's milk cheeses currently produced in Galicia (NW Spain). Swiss Soc. of Food Sci. and Technol.

Gobbetti, M., Smacchi, E., Fox, P., Stepaniak, L., \& Corsetti, A. The Sourdough Microflora, Cellular Location and Characterization of Proteollytic Enzymes in Lactic Acid Bacteria. Academic Press Limited. Halaman 561-569.

Lestari L.A., Harmayani, E., \& Marsono, Y. 2004. Efek hipokolesterolemik yogurt yang disuplementasi probiotik 64. Agrosains 17: 51-

Nakazawa Y. \& Hosono, A. 1992. Function of fermented milk. Challenges for The Health Sciences: 180-184S.

Nisa, F.Z., Marsono, Y., \& Harmayani, E. 2006. Efek hipokolesterolemik susu kedelai femetasi steril pada model hewan coba. Agrosains 19: 41-53.

Piraino, P., Zotta, T., Ricciardi, A., McSweeney, P.L.H. \& Parente, E. 2008. Acids production, proteolysis, autolytic and inhibitory properties of lactic acid bacteria isolated from pasta filata cheese: A multivariate screening study. Int. Dairy Journal 18: 81-92

Rahayu, E.S. \& Margino, S. 1997. Bakteri Asam Laktat : Isolasi dan Identifikasi. Materi Workshop, diselenggarakan oleh PAU Pangan Gizi. Universitas Gadjah Mada. Yogyakarta, 13-14 Juni 1997.

Schlegel, H.G. 1994. Mikrobiologi Umum Ed. Ke 6. Yogyakarta: Gadjah Mada University Press.

Steamer, J.R. 1979. Lactic acid bacteria. Di dalam: de Fuguiredo M.P. \& Splittoesser, D.F. Food Microbiology. Public Health and Spoilage aspect. Westport: AVI Pub.

Wood, B.J.B. 1992. The Lactic Acid Bacteria in Health and Deseases. London: Blackie Academic and Professional. 